\title{
V. sjezd České společnosti kardiovaskulární chirurgie s mezinárodní účastí v Brně
}

Hotel Voroněž v Brně přivítal ve dnech 4.-6. listopadu 2012 účastníky V. sjezdu České společnosti kardiovaskulární chirurgie. Tento sjezd, který se koná vždy jednou za dva roky, zcela zaplnil všechny sály hotelu Voroněž, který optimálním způsobem splnil všechny požadavky organizátorů kongresu. Na tomto sjezdu, kterého se zúčastnili především srdeční a cévní chirurgové, ale i endovaskulární specialisté, kardiologové, anesteziologové, radiologové, perfuzionisté, zdravotní sestry a další odborníci, bylo registrováno 494 lékařů a sester a 90 firemních zástupců. Je potěšující, že kromě českých odborníků, jichž byla převaha, se našeho sjezdu zúčastnili i četní odborníci převážně ze Slovenska a z Rakouska, ale i z Německa, Bosny a Hercegoviny, Srbska, Japonska a Norska. Bylo předneseno celkem 168 přednášek, z toho 74 v kardiochirurgické sekci, 66

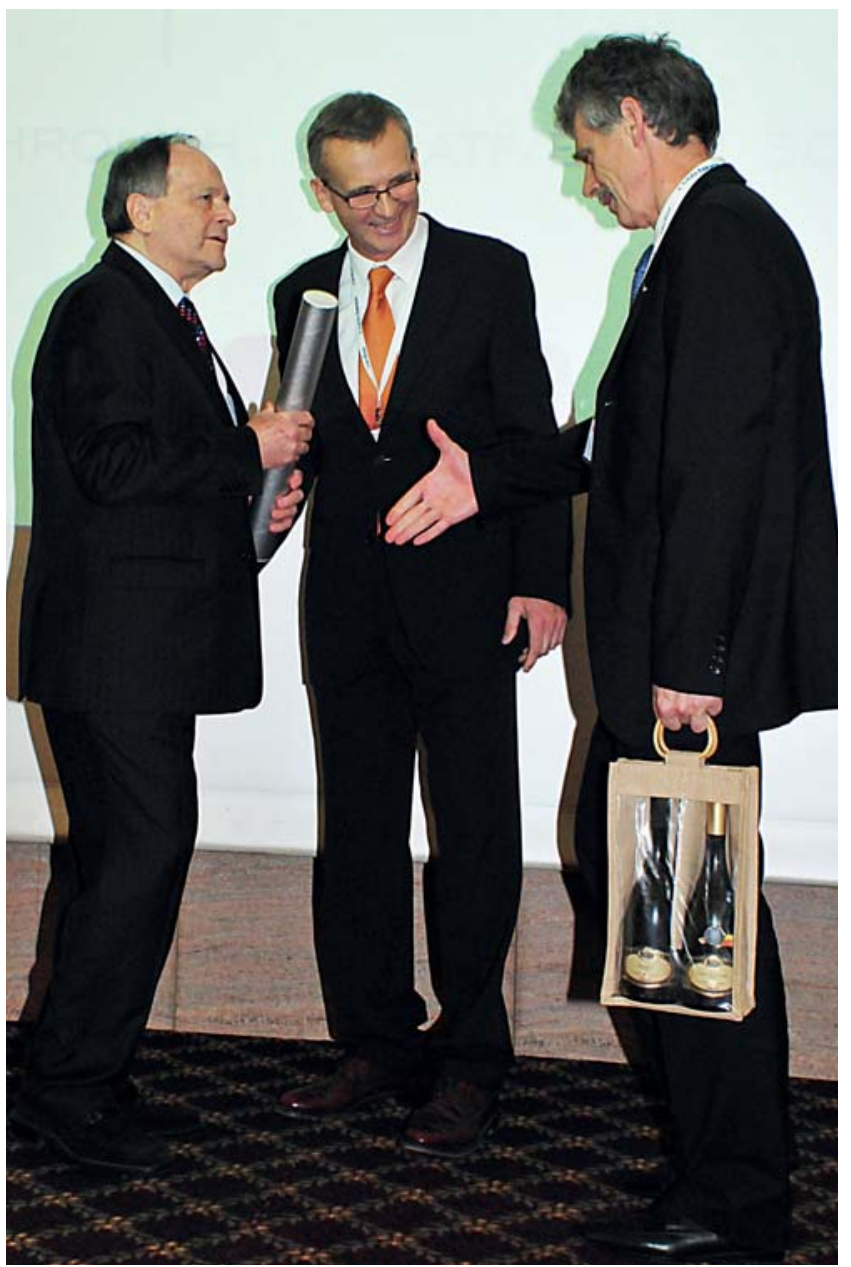

Obr. 1 - Doc. Němec spolu s doc. Šebestou předávají čestné členství naší společnosti prof. Šefránkovi. v sekci cévní chirurgie, 28 v sekci sester a bylo vystaveno 28 posterů. $V$ anglickém jazyce bylo předneseno 15 přednášek.

Sjezd proběhl paralelně ve čtyřech odborných sekcích: Byla to sekce kardiochirurgická, sekce cévní chirurgie, sekce sester a posterů. Součástí sjezdu byla firemní výstava, na které se podílely všechny firmy, jež náš sjezd sponzorovaly.

Sjezd byl zahájen již v neděli odpoledne odbornými symposii firem Johnson \& Johnson a Edwards Lifesciences a workshopy, které zorganizovaly firmy B. Braun Medical, MAQUET, E.M.S., Covidien a Biomedica. Večerní welcome drink měl príijemnou neformální atmosféru.

Oficiální a slavnostní zahájení našeho V. sjezdu se uskutečnilo v pondělí ráno před zcela zaplněným sálem hotelu Voroněž. Domácí i zahraniční účastníky přivítal předseda organizačního výboru prof. Staffa a informoval o změnách $v$ organizaci $V$. sjezdu naší společnosti oproti předcházejícím sjezdům. Předseda naší společnosti doc. Němec poté kongres oficiálně zahájil a přednesl úvodní referát, ve kterém zhodnotil současný stav srdeční a cévní chirurgie v České republice. Zdůraznil, že česká srdeční i cévní chirurgie drží důstojně krok s předními evropskými a světovými pracovišti a zavádí moderní operační postupy především v chlopenní chirurgii, používá méně invazivní operační přístupy a dostává se na čelné místo i v robotické cévní chirurgii. Zdůraznil význam úzké spolupráce kardiochirurgů s intervenčními kardiology při transfemorální a transapikální implantaci aortálních bioprotéz, přičemž upozornil na skutečnost, že $v$ našem státě jsme $v$ tomto směru na rozdíl od našich západních sousedů velmi limitováni zdravotními pojištovnami v počtu prováděných výkonů.

V rámci slavnostního zahájení našeho sjezdu byli jmenováni čestnými členy naší odborné společnosti prof. Černý (Brno) a prof. Šefránek (Bratislava) za jejich celoživotní práci a úspěchy, kterých dosáhli v oblasti srdeční a cévní chirurgie (obr. 1). Následně byly vyhodnoceny nejlepší odborné práce a monografie z oblasti srdeční a cévní chirurgie za rok 2011. Cenu za nejlepší monografii v kardiochirurgii obdrželi prof. Dominik a doc. Žáček za knihu Heart Valve Surgery, kterou nakladatelství Springer vydalo nejprve v angličtině a poté $v$ čínštině. Tato výjimečně zdařilá publikace si tuto cenu zcela jistě zasloužila a je potěšitelné, že nyní bude prezentovat vysokou úroveň české kardiochirurgie i v Číně (obr. 2). Cenu za nejlepší publikaci v kardiochirurgii obdržel kolektiv autorů M. Pojar, J. Vojáček, M. Tauchman a spol. za práci Thoracoscopic left ventricular lead implantation, cenu za nejlepší publikaci v cévní chirurgii obdrželi T. Novotný, M. Dvořák a R. Staffa za práci The learning curve of robot assisted laparoscopic aortofemoral bypass grafting for aortoiliac occlusive disease 


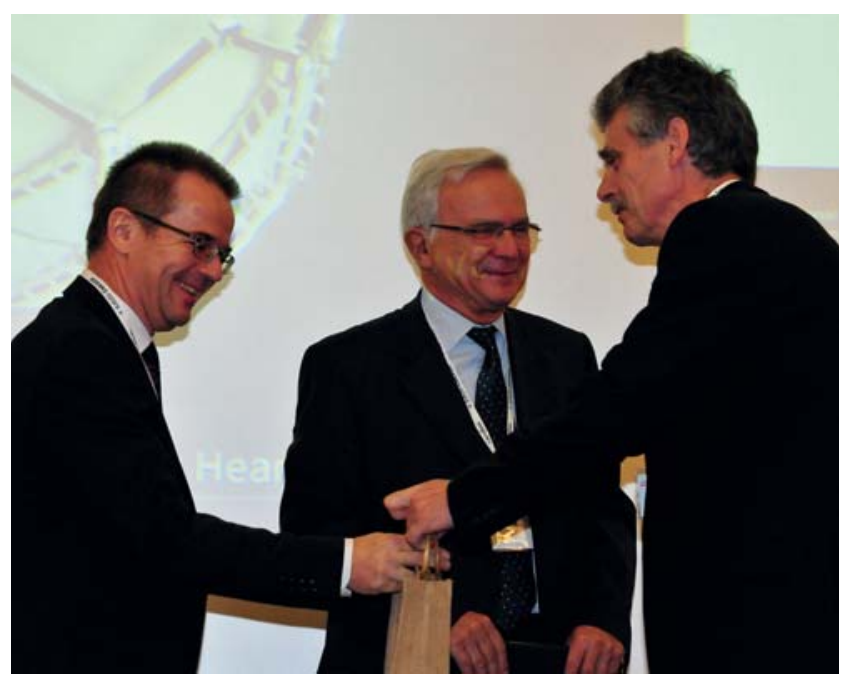

Obr. 2 - Prof. Třeška spolu s doc. Němcem předávají prof. Dominikovi a doc. Žáčkovi Cenu za nejlepší monografii v kardiochirurgii za rok 2011.

publikovanou v prestižním Journal of Vascular Surgery (obr. 3).

Po slavnostním zahájení následovaly tradičně slavnostní přednášky. Navrátilovu přednášku s názvem Chirurgická léčba ICHS včera, dnes a zítra přednesl doc. Harrer. Svého oblíbeného tématu se zhostil na výtečnou, seznámil nás s historií léčby ICHS a se současnými moderními postupy. Obhajoval operace na koronárních tepnách bez užití mimotělního krevního oběhu, kterých dnes provádějí v Hradci Králové asi 50 \% s vynikajícími výsledky. Hejhalovu přednášku na téma Periferní bypass v éře endovaskulárního boomu přednesl prof. Staffa, který poukázal na nutnost nikoliv soutěže, nýbrž úzké spolupráce mezi angiochirurgy a endovaskulárními specialisty při léčbě periferních tepenných lézí a na největším souboru v rámci ČR demonstroval, že kriticky ischemickou končetinu je možné zachránit pedálním žilním bypassem.

Následovaly dvě slavnostní vyžádané přednášky zahraničních autorů. Prof. Fraedrich z Innsbrucku přednesl sdělení Guidelines of the ESVS and actual aspects for the management of abdominal aortic aneurysms (obr. 4) a prof. Laufer z Vídně přednesl Long-term outcome after the Ross operation (obr. 5). Těmito přednáškami byla ukončena slavnostní část, dále se již odborný program sjezdu rozdělil na dvě paralelní sekce - kardiochirurgickou a angiochirurgickou, ke kterým se další den ještě připojila sekce sesterská.

\section{A/ Kardiochirurgie}

Nejvíce přednášek bylo věnováno plastikám a záchovným operacím aortální chlopně. Z nich je třeba vyzvednout úvodní přednášku D. Aicher z Homburgu a následně přednášku P. Žáčka (Hradec Králové), které byly přehledné a velmi dobře dokumentovány obrázky a schématy, na nichž byl vidět nepřehlédnutelný Žáčkův rukopis. Je potěšující, že plastiky aortální chlopně dnes provádějí všechna kardiochirurgická pracoviště v ČR, přičemž vycházejí z konceptu Schafersovy metody. V pondělí odpoledne proběhla Soutěž mladých chirurgů do 35 let, která byla poprvé zařazena do programu sjezdu. V kardiochirurgické části soutěže bylo předneseno devět sdělení. Přednášky byly velmi dobře dokumentovány a setkaly se s velkým zájmem posluchačů. První cenu spojenou s finanční odměnou ve výši 10000 Kč obdržel M. Špaček spolu s kolektivem lékařů z VFN Praha za práci Izolovaná perfuze končetin s použitím TNF , 2. cenu získal P. Budera s kolektivem autorů za multicentrickou studii PRAGUE-12, 3. cenu obdržel P. Fila (CKTCH Brno) za práci Záchovné operace aortální chlopně u pacientů nad 60 let.

Jeden blok přednášek byl věnován chirurgické léčbě ICHS, kdy autoři srovnávali výsledky operací s využitím a bez využití mimotělního krevního oběhu s tím, že mezi oběma skupinami nebyly zjištěny podstatné rozdíly.

V úterý odborný program pokračoval ve všech třech sekcích. Sesterská sekce zahrnovala dva kardiochirurgické bloky a jeden angiochirurgický blok přednášek, které proběhly před zaplněným sálem.

Úterní kardiochirurgický program byl zaměřen na mechanickou srdeční podporu, mimotělní krevní oběh, vrozené srdeční vady, chirurgii hrudní aorty a varia. První blok přednášek proběhl v režii IKEM, za který bylo předneseno pět sdělení týkajících se programu mechanické srdeční podpory v IKEM. Zajímavá byla sdělení referující o použití ECMO v léčbě respiračního a oběho-

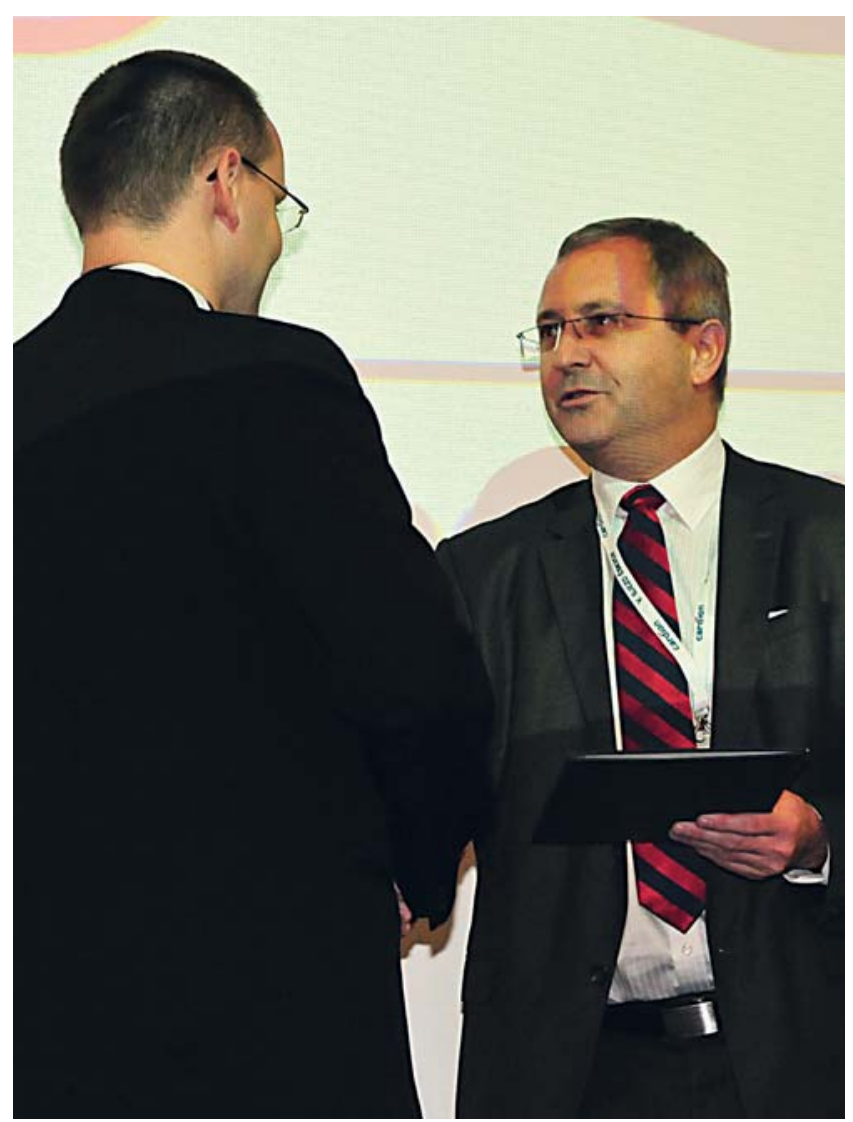

Obr. 3 - MUDr. Novotný z FN u sv. Anny v Brně přebírá cenu za nejlepší publikaci $v$ cévní chirurgii. 


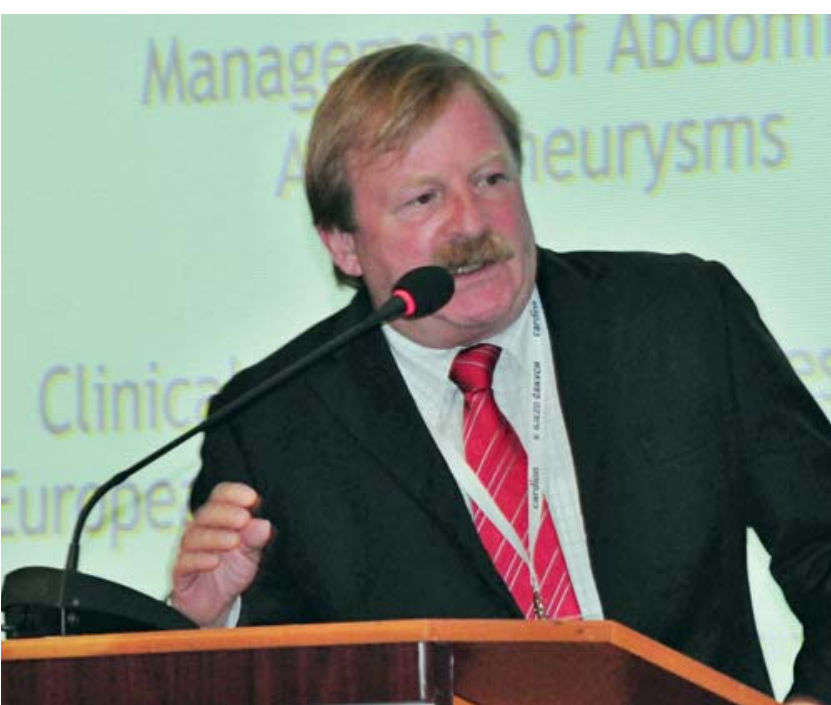

Obr. 4 - Prof. Fraedrich z Innsbrucku při slavnostní přednášce Guidelines of the ESVS and actual aspects for the management of abdominal aortic aneurysms

vého selhání a přednáška J. Slavíka (Brno) o výsledcích léčby končetinových nádorů hypertermickou izolovanou perfuzí cytostatiky. V. Lonský přednesl přehledné sdělení Současný mimotělní oběh z pohledu medicíny založené na důkazech, ve kterém zdůraznil nepříznivé účinky koronárního sání na krevní elementy. Přednášky z Dětského kardiocentra v Motole prezentovaly vynikající výsledky tohoto pracoviště v léčbě komplexních vrozených srdečních vad. V bloku chirurgie hrudní aorty byly předneseny výsledky chirurgické a endovaskulární léčby u nemocných $s$ výdutí a rupturou descendentní hrudní aorty. Bylo konstatováno, že endovaskulární implantace stentgraftu u nemocných s poraněním descendentní aorty je dnes suverénní metodou léčby, která přináší lepší výsledky než operace.

\section{B/ Cévní chirurgie}

Úvodní pondělní bloky v cévní chirurgii se věnovaly aktuálním otázkám v léčbě akutní a chronické končetinové ischemie, komplikacím v cévní chirurgii a cévním hemodialyzačním přístupům. Blok zahájil vyzvanou přednáškou T. Hölzenbein ze Salzburgu na téma využití alternativních zdrojů žilních štěpů u distálních bypassů. Zdůraznil přednosti žilní náhrady oproti syntetickým protézám a představil v současnosti ne zcela běžné možnosti jejich získání, např. z vena saphena parva nebo z žil horní končetiny. Následovala sdělení pojednávající o biosyntetických cévních protézách nebo náhradách vytvořených in vitro endotelizací cévních protéz. $\mathrm{V}$ bloku věnovaném komplikacím $v$ cévní chirurgii byla nejvíce diskutována problematika infekce aortální cévní protézy. Doc. A. Neufang z Wiesbadenu ve vyžádané přednášce demonstroval vynikající výsledky při řešení této komplikace autologní femorální žilou (obr. 6). Hlavní výhodou této metody, kterou využívají i některá naše pracoviště, jsou minimální rizika reinfekce a okluze štěpu. Velmi dobrých výsledků, jak zaznělo v dalších sděleních, bylo docíleno rovněž použitím alograftů při náhradě infikované aortální protézy. Standardní metodou zůstává extraanatomický bypass nebo in situ rekonstrukce pomocí cévní protézy $s$ antimikrobiální úpravou ( $V$. Třeška, FN Plzeň). Další pondělní blok byl věnován thorakoabdominální aortě, robotice a laparoskopickým cévním výkonům. Řada sdělení se věnovala jak endovaskulárnímu, tak otevřenému angiochirurgickému řešení aortálních výdutí. Pozitivní je skutečnost, že také v ČR již existují pracoviště připravená řešit rupturu výdutě břišní aorty stentgraftem. Sdělení, která se týkala robotiky v cévní chirurgii, přednesli autoři ze dvou pracovišt', jež se touto problematikou zabývají (P. Štádler, Nemocnice Na Homolce a M. Dvořák, FN u sv. Anny v Brně).

Také v angiochirurgické části soutěže mladých chirurgů zazněla řada kvalitních přednášek. 1. cenu získal S. Rokošný a kolektiv autorů z IKEM Praha za práci Aneurysmorafie AVF s použitím Aneurysmorrhaphy Clamp, 2. místo obsadil M. Pirkl se spoluautory z Pardubic za sdělení Vakuová drenáž jako možnost terapie infektu infrainguinální protetické rekonstrukce a 3. cenu obdržel R. Fiala (FN Motol, Praha) za práci Poranění tepen $v$ dětském věku - střednědobé sledování.

Velkým přínosem byla také bohatá účast endovaskulárních specialistů (G. Mertikian z Vídně, D. Kučera z Ostravy, M. Köcher z Olomouce a další), kteří představili svoje výsledky nejen v úterním endovaskulárním

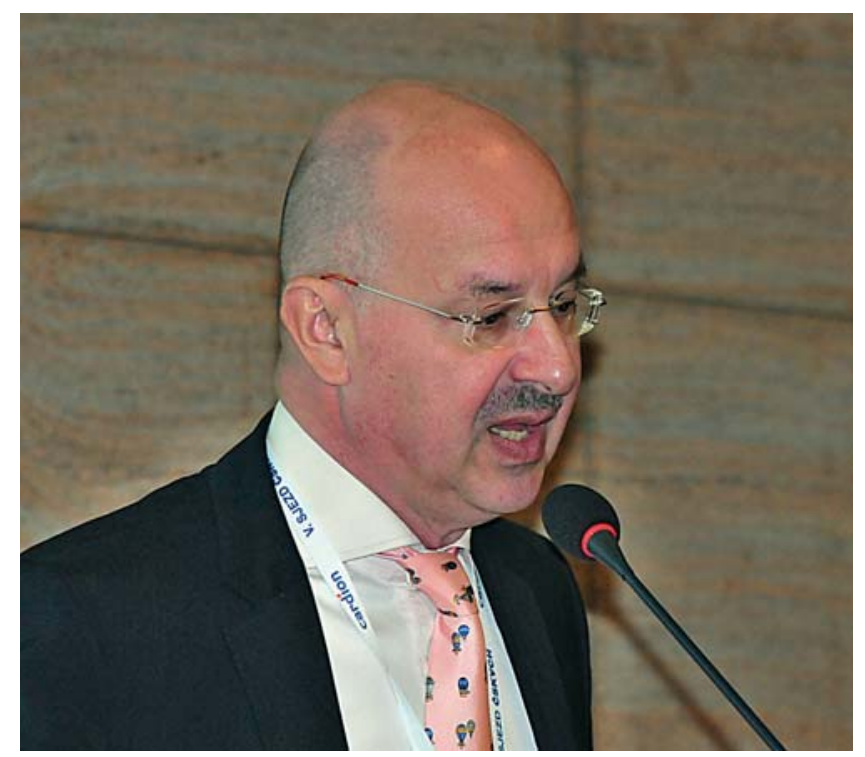

Obr. 5 - Prof. Laufer za přednáškovým pultem

a hybridním bloku. $\mathrm{V}$ bloku zaměřeném na karotické povodí vyvolaly diskusi přednášky týkající se časování operace krkavic po mozkové příhodě (urgentní a časná karotická endarterektomie). K velmi zajímavým patřila rovněž sdělení na téma simultánní výkony na karotickém řečišti a na myokardu. $V$ rámci bloku věnovaného žilní chirurgii a variím přednesli kolegové z FN Olomouc sdělení o neovaskularizaci po klasické operaci varixů a dále zaznělo zajímavé sdělení o možnosti léčby lymfedému pomocí lymfovenózní anastomózy. 


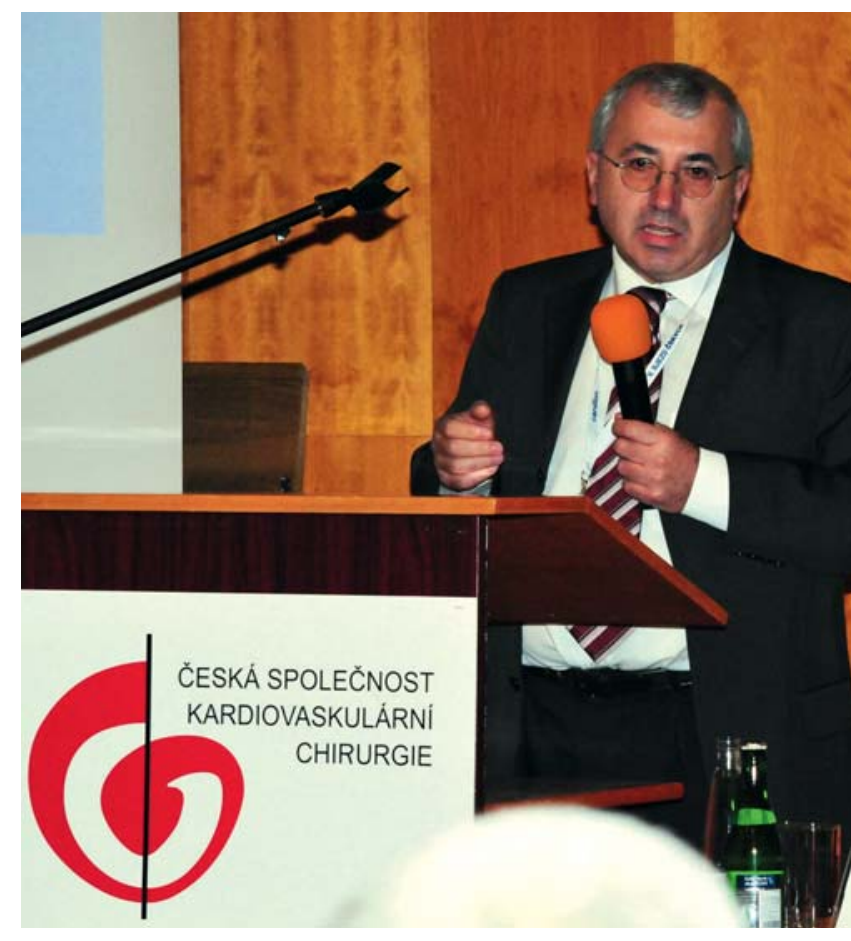

Obr. 6 - Doc. Neufang z Wiesbadenu demonstruje výsledky řešení infekce aortální cévní protézy pomocí autologní femorální žíly.

Celkového zhodnocení průběhu V. sjezdu naší společnosti se ujali za kardiochirurgickou sekci prim. Černý a za angiochirurgickou sekci prof. Šefránek. Konstatovali, že přednesená sdělení byla vysoce kvalitní a velmi dobře dokumentována. Ukázala, že česká kardiochirurgie a cévní chirurgie dosahují vynikající odborné úrovně, která obstojí v mezinárodním srovnání. Poděkovali zástupcům firem za sponzorování našeho sjezdu a organizátorům sjezdu za jeho hladký průběh a vysokou celkovou úroveň.

Zlatým hřebem našeho sjezdu byl společenský večer, který se konal ve všech spojených sálech hotelu Voroněž a jehož se zúčastnilo 450 účastníků sjezdu. Dvě hudební produkce odlišných žánrů vytvořily príijemnou atmosféru, ke spokojenosti účastníků přispělo vynikající jídlo a kvalitní vína z jižní Moravy.

Závěrem je třeba zdůraznit, že organizační změny v konání sjezdu, které zavedl výbor naší odborné společnosti, byly velmi kladně přijaty účastníky sjezdu. Soutěž mladých chirurgů, workshopy a větší prostor pro endovaskulární specialisty budou zcela jistě pokračovat i při následujících sjezdech stejně tak jako vyžádané přednášky zahraničních odborníků. Za největší klad tohoto sjezdu považujeme skutečnost, že naše odborná společnost navazuje odborné kontakty se zahraničím, a tak se připravuje na budoucí sjezdy, které se budou stále více otevírat světu.

Prof. MUDr. Jan Černý, CSc., Centrum kardiovaskulární a transplantační chirurgie, Brno, e-mail: jan.cerny@cktch.cz; prof. MUDr. Robert Staffa, Ph.D., II. chirurgická klinika, Lékařská fakulta Masarykovy univerzity a Fakultní nemocnice u sv. Anny v Brně 